sodium carbonate in a 1:0.85:0.6 molar ratio. The crystals of 1 were handpicked for $\mathrm{X}$-ray diffraction and magnetic measurements. Correct elemental analysis (C, H. $\mathrm{N}, \mathrm{Cu}$ )

Received: January 3,1994 [Z 6594 IE] German version: Angew: Chem. 1994, 106. 1223

[1] J. M. Berg. R. H. Holm in Iron-Sulfur Protcins, Vol. 4 (Ed.: T. G. Spiro), WileyInterscience. New York, 1982, Chap. 1; R. H. Holm, S. Ciurli, J. A. Weigel, Prog. Inorg. Chem. 1990, 38, 1

[2] R. Mergehenn. W. Haase, Acta Crystallogr. Sect B 1977, 33. 1877, 2734; L. Merz, W. Haase, J. Chem. Soc. Dahon Trans. 1978, 1594; ibid. 1980, 875; H. Astheimer. F. Nepveu. L. Walz, W. Haase, ibid. 1985. 315; L. Schawabe, W. Halase, ibid. 1985, 1909

[3] J. W. Hall, W. E. Estes. E. D. Estes, R. P. Scaringe, W. E. Williams, Inorg. Chem. 1977. 16, 1572; N. Matsumoto. T. Tsutsumi. A. Ohyoshi, H. Okawa, Bull. Chen. Soc. Jpn. 1983, 56, 1388.

[4] J. Sletten. A. Sørensen. M. Julve, Y. Journaux, Inorg. Chem. 1990, 29, 5054.

[5] I. Castro, M. Julve, G. De Munno, G. Bruno, J. A. Real, F. Lloret, J. Faus, J. Chem. Sor. Dalton Trans. 1992, 1739.

[6] G. De Munno, M. Julve, F. Lloret, J. Faus, M. Verdaguer. A. Caneschi, Angew. Chem. 1993. 105. 1122; Ange'w. Chem. Int. Ed. Engl. 1993, 32, 1046.

[7] M. L. Kirk. W. E. Hatfield, M. S. Lah, D. Kessissoglou, V. Pecoraro. L. W. Morgan, J. D. Petersen. J. Appl. Phis. 1991, 69, 6013.

[8] X-ray structure analysis: Siemens $\mathrm{R} 3 \mathrm{~m} / \mathrm{V}$ automatic diffractometer, $\mathrm{Mo}_{\mathbf{k}_{\boldsymbol{x}} \text {, }}$, $\lambda=0.71073 \AA$. graphite monochromator, $298 \mathrm{~K}$. Lorent $z$ polarization and $\Psi$. scan absorption correction [9]. Data collection, solution, and refinement: $\omega$ 20, standard Patterson methods with subsequent Fourier recycling, SHELXTL-PUS [10]. Two nitrate groups and a water molecule are disordered. The disorder of cach nitrate anion has been treated assuming a population factor of 0.5 for the nitrogen and for one of the oxygens. The oxygen of the disordered water was also given a 0.5 population factor. Data collection on a different crystal of $I$ was also carried out at $120 \mathrm{~K}$ in order to reduce the degree of disorder and to get a more accurate description of its structure. Unfortunately, the disorder was not reduced by cooling. thus proving that it is mainly statistical. Only the structural data at room temperature are reported because the final discrepancy indices at low temperature were not better. All non-hydrogen atoms, except the oxygen atoms of water molecules, and oxygen and nitrogen atoms of disordered nitrate groups. were refined anisotropically. The hydrogen atoms of the bpym ligand were set in calculated positions and refined as riding atoms. They were all refined isotropically. Final geometrical calculations and graphical manipulations were performed with the PARST program [11] and the XP utility of the SHELX-PLUS system, respectively. 1: $\mathrm{C}_{48} \mathrm{H}_{50} \mathrm{~N}_{30} \mathrm{Cu}_{7} \mathrm{O}_{29}\left(M_{\mathrm{r}}=1937.9\right)$, triclinic, space group $P \overline{1}, a=11.553(7), b=$ 13.164(7), $c=13.419(8) \AA . \quad x=70.66(4), \beta=82.21(5), \quad \gamma=64.14(4)^{\circ} . \quad V=$ $1733(2) \AA^{3}, Z=1, \rho_{\text {colkd }}=1.857 \mathrm{~g} \mathrm{~cm}^{-3}, \mu=22.13 \mathrm{~cm}^{-1} .2 \theta$ range $3-54^{\circ}$, crystal size $0.34 \times 0.18 \times 0.08 \mathrm{~m}^{3}, F(000)=967.7581$ unique reflections, 3862 observed with $J>3 \sigma(I), 498$ parameters, $R\left(F_{\mathrm{v}}\right)=0.0744, R_{w}\left(F_{\mathrm{o}}\right)=0.0795$ and $S=1.735$ with $w^{-1}=\sigma^{2}\left(F_{0}\right)+0.0021\left(F_{0}\right)^{2}$. Further details of the crystal structure investigations are available on request from the Fachinformationszentrum Karlsruhe. D-76344 Eggenstein-Leopoldshafen (FRG), on quoting the depository number CSD-58070 and the journal citation.

[9] A. C. T. North, D. C. Philips, F. S. Mathews, Acta Cry'stallogr. Sect. A 1968, 24,351

[10] SHELXTL PLUS, Version 4.21/V. Siemens Analytical X-Ray Instruments Inc., Madison. WI. 1990.

[11] M. Nardelli. Computer. Chem. 1983, 7, 95.

[12] Bond distances and angles in the bpym ligands are in agreement with those reported in the literature. The pyrimidyl rings of bpym are planar. However, the bpym as a whole is not planar: the dihedral angles between the pyrimidyl rings of the bpym ligands bound to $\mathrm{Cu}(1), \mathrm{Cu}(2)$ and $\mathrm{Cu}(3)$ are 3.6(3), 2.5(3), and $4.6(4)^{\circ}$, respectively.

[13] At first we considered only the interactions within the two dimers and the trinuclear entity and the best fit was made on $J_{1}$ and $J_{3}$ as variables with $J_{2}=J_{4}=0$. Then we kept these $J_{1}$ and $J_{3}$ values constant and fit on $J_{2}$ and $J_{4}$. This procedure is continued until self-consistent values for all parameters are found.

[14] W. E. Hatfield in Magneto-Structural Correlations in Exchange Coupled Sy stems (Eds.: R. D. Willett, D. Gatteschi, O. Kahn), NATO ASI Ser., Ser. C 1985. 140,555

\section{The First Zwitterionic, Optically Active Disilicate with Pentacoordinate Silicon**}

Reinhold Tacke, ${ }^{*}$ Mathias Mühleisen, and Peter G. Jones

The study of compounds with higher coordinate silicon atoms is currently one of the main areas of research in silicon chemistry. ${ }^{[1]}$ In the past few years, ionic $\lambda^{5} \mathrm{Si}$-silicates have been investigated particularly intensively. With the systematic elaboration of a new class of substances, the spirocyclic zwitterionic $22^{5} \mathrm{Si}-$ silicates, this area of research has recently expanded. ${ }^{[2,3]}$ These compounds are neutral molecular $\lambda^{5} \mathrm{Si}$-silicates in which two diolato(2-) ligands and one ammonio-substituted organic group are bound to the Si coordination center. The bidentate diolato(2-) ligands thus far employed are derived from diols of the catechol and glycolic acid types. The zwitterions $1^{[2 \mathrm{e}]}$ and $2,{ }^{[2 \mathrm{~h}]}$ which may be classified as molecular mononuclear complexes of pentacoordinate silicon, are typical examples of this class of
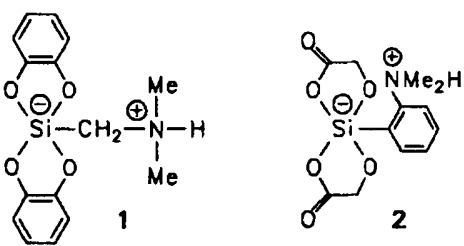
compounds.

With the synthesis of (+)-bis[(ammonio)methyl]bis $[\mu-(R, R)$ tartrato(4-)- $O^{1}, O^{2}: O^{3}, O^{4}$ disilicate $(+)-4$, we have now succeeded in obtaining a molecular binuclear $\lambda^{5} \mathrm{Si}^{2},{ }^{5} \mathrm{Si}^{\prime}$-silicon complex for the first time (Scheme 1). In this compound, two tetra-

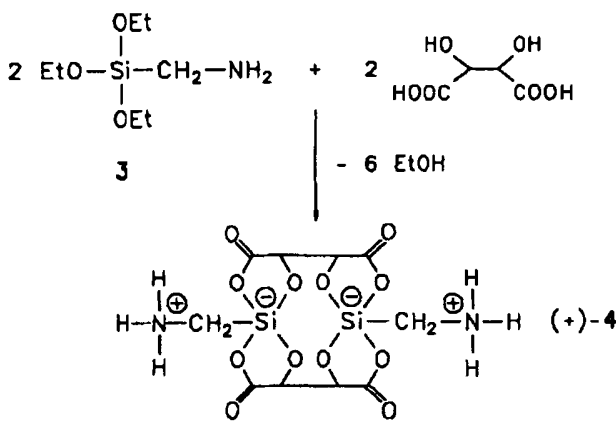

Scheme 1. Synthesis of the disilicate (+)-4 from (aminomethyl)triethoxysilane 3 and $(R, R)-(+)$-tartaric acid

dentate $(R, R)$-tartrato(4-) ligands bridge the two Si atoms, and each ligand bonds to each of the $\mathrm{Si}$ atoms at two coordination sites. The disilicate $(+)-4$ has a pentacyclic molecular framework and contains two pentacoordinate (formally negatively charged) $\mathrm{Si}$ atoms and two tetracoordinate (formally positively charged) $\mathrm{N}$ atoms. To the best of our knowledge, this is the first

[*] Prof. Dr. R. Tacke, Dipl.-Chen. M. Mühleisen

Institut für Anorganische Chemie der Universität

Engesserstrasse, Geb. 30.45

D.76128 Karlsruhe (FRG)

Telefax: Int. code (721) 608-4290

Prof. Dr. P. G Jones

Institut für Anorganische und Analytische Chemie

der Technischen Universität Braunschweig

[**] This work was supported by the Deutsche Forschungsgemeinschaft and the Fonds der Chemischen Industrie. 
optically active compound of pentacoordinate silicon. Its optical activity results from the presence of the two chiral $(R, R)$-tartrato(4-) ligands and the two chiral $\mathrm{Si}\left(\mathrm{OO}^{\prime}\right)_{2} \mathrm{C}$ units

Compound $(+)-4$ was prepared by reaction of (aminomethyl)triethoxysilane ${ }^{[4]} 3$ with $(R, R)-(+)$-tartaric acid (molar ratio 1:1) in aqueous solution and isolated as a 2:1 mixture of $(+)-4$ and $(+)-4 \cdot 3 \mathrm{H}_{2} \mathrm{O}$ (yield approx. $88 \%$ ). The formation of $(+)-4$ $(100 \%$ ee, $100 \%$ de) occurred stereospecifically. Compounds $(+)-4$ and $(+)-4 \cdot 3 \mathrm{H}_{2} \mathrm{O}$ were obtained in pure form by mechanical sorting and then characterized. ${ }^{[5]}$ The trihydrate was structurally characterized by $\mathrm{X}$-ray diffraction on a single crystal; ${ }^{[6]}$ this was not possible in the case of the water-free compound because of its poor crystal quality.

The molecular structure of $(+)-4$ in the crystal of (+)4. $3 \mathrm{H}_{2} \mathrm{O}$ is shown in Figure 1. The coordination polyhedra sur-

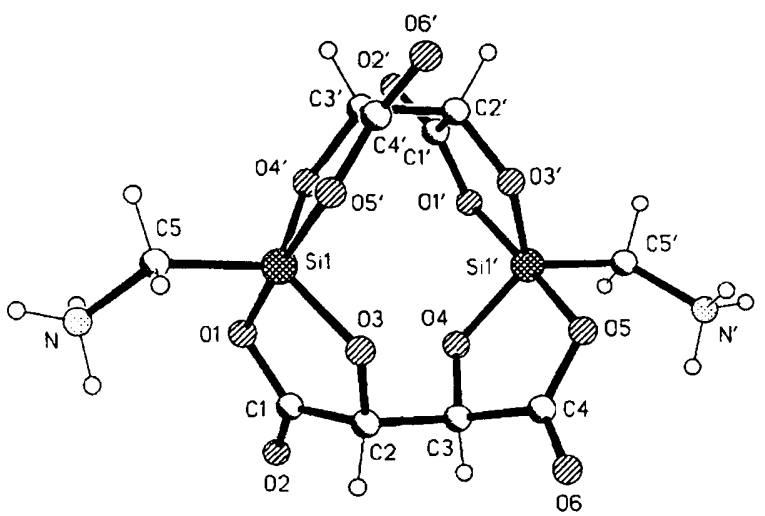

Fig. 1. Molecular structure of $(+)-4$ in the crystal of $(+)-4 \cdot 3 \mathrm{H}_{2} \mathrm{O}$. Selected distances [pm] and angles ["] (standard deviations in parentheses): Si1-O1 179.1(2). Si1-O3 167.5(2), Si1-O4' 166.5(2), Si1-OS' 182.0(2), Si1-C5 188.5(3), Si1'-O1' 182.5(2). Sil'-O3' 166.9(2), Si1'-O4 166.6(2), Si1'-O(5) 179.7(2), Si1'-C5' 188.4(3); O1-Si1-O3 89.07(9), O1-Si1-O4' 90.06(10), O1-Si1-O5' 175.56(9), O1-Si1-C5 95.45(11). O3-Si1-O4' 121.18(10), O3-Si1-O5' 87.85(9), O3-Si1-C5 120.04(12), O4'Si1-O5' 88.79(9). O4'-Si1-C5 118.58(12), O5'-Si1-C5 88.87(11), O1'-Si1'-O3' 88.21(9), O1'-Si1'-O4 88.87(9), O1'-Si1'-O5 175.13(9), O1'-Si1'-C5' 89.28(11), O3'$\mathrm{Si}^{\prime}-\mathrm{O} 4$ 122.57(10). O3'-Si1'-O5 88.68(9), O3'-Si1'-C5' 120.23(11), O4-Si1'-O5 89.64(9). O4-Si1'-C5' 117.06(11), O5-Sil'-C5' 95.52(11). - The molecular symmetry of $(+)-4$ may be described as approximately $D_{2}$ if the ammoniomethyl groups are ignored.

rounding the atoms Si 1 and $\mathrm{Si} 1^{\prime}$ can be described to a first approximation as slightly distorted trigonal bipyramids [transition trigonal bipyramid $\rightarrow$ square pyramid: $7.7 \%$ Si $1 ; 10.6 \%$ Si 1'], ${ }^{[7]}$ in which each of the axial positions is occupied by carboxylate oxygen atoms. Several intermolecular $\mathrm{N}-\mathrm{H} \cdots \mathrm{O}$ and $\mathrm{O}-\mathrm{H} \cdots \mathrm{O}$ hydrogen bonds are present in the crystal structure of $(+)-4 \cdot 3 \mathrm{H}_{2} \mathrm{O}$. The construction of the three-dimensional $\mathrm{H}$ bonding system is complicated and characterized by a large acceptor excess (D/A ratio $12: 30$ ), such that generally only one of the acceptor sites on the oxygen atoms is used (exceptions: use of two acceptor sites by the carbonyl oxygen atoms $\mathrm{O} 2, \mathrm{O}^{\prime}$, and ${ }^{\prime} 6^{\prime}$ as well as nonparticipation of the atoms $04, \mathrm{O}^{\prime}$, and $O 5^{\prime}$ in hydrogen bonding).

It follows from NMR spectroscopic investigations ${ }^{[8]}$ that the zwitterionic binuclear complex $(+)-4$ is also present in solution $\left(\left[\mathrm{D}_{6}\right] \mathrm{DMSO}, \mathrm{D}_{2} \mathrm{O}\right)$. The presence of pentacoordinate Si atoms of the type $\mathrm{SiO}_{4} \mathrm{C}$ is clearly indicated by the characteristic ${ }^{29} \mathrm{Si}$ chemical shifts ([D 6 DMSO: $\left.\delta=-91.7 ; \mathrm{D}_{2} \mathrm{O}: \delta=-90.0\right)$, and the presence of tetracoordinate $\mathrm{N}$ atoms of the ammonium type can be indirectly confirmed by the identification of the $\mathrm{NH}_{3}$ group by ${ }^{1} \mathrm{H}$ NMR spectroscopy ([D 6 DMSO $: \delta=7.1$ ).
The results presented here suggest that a rich complex chemistry of higher coordinate silicon in aqueous solution may be developed, in which diolato ligands derived from natural products (such as tartaric acid in this case) are of particular interest: it has been speculated in the literature ${ }^{[9]}$ that silicon transport in biological systems might be based on higher coordinate Si species, and complexes such as the title compound could be of interest as model systems in this respect.

\section{Experimental Procedure}

$(+)-4 /(+)-4 \cdot 3 \mathrm{H}_{2} \mathrm{O}: 3[4](800 \mathrm{mg}, 4.14 \mathrm{mmol})$ was added to a stirred solution of $(R . R)-(+)$-tartaric acid $(622 \mathrm{mg} .4 .14 \mathrm{mmol})$ in water $(120 \mathrm{~mL})$ at room temperature. The resulting clear solution was concentrated at $60^{\circ} \mathrm{C} / 40$ Torr to a volume of $100 \mathrm{~mL}$ and then allowed to stand undisturbed at room temperature for $96 \mathrm{~h}$ (formation of the first crystals ca. $24 \mathrm{~h}$ after the reactants were mixed). The solid formed was filtered off and washed with ethanol $(3 \times 10 \mathrm{~mL})$ and then dried at room temperature in a nitrogen stream; yield $780 \mathrm{mg}(\mathrm{ca} .88 \%)$ of a crystal mixture composed of $(+)-4$ (colorless, thin needles) and $(+)-4 \cdot 3 \mathrm{H}_{2} \mathrm{O}$ (colorless rhombuses) in at ratio of roughly 2:1 ( ${ }^{1} \mathrm{H}$ NMR spectroscopic determination of the proportion of $\mathrm{H}_{2} \mathrm{O}$ in the mixture) $(+)-4$ and $(+)-4 \cdot 3 \mathrm{H}_{2} \mathrm{O}$ were isolated in pure form by mechanical sorting under the microscope

$(+)-4:$ M.p $>350^{\circ} \mathrm{C}:[x]_{580}^{20}=+86$ (DMSO, $\left.c=1.00\right)$; correct $\mathrm{C} . \mathrm{H}, \mathrm{N}$ analysis: ${ }^{1} \mathrm{H} \mathrm{NMR}\left(\left[\mathrm{D}_{6}\right] \mathrm{DMSO}\right): \delta=2.05$ (br. s. $2 \mathrm{H} ; \mathrm{SiCH}_{2} \mathrm{~N}$ ), 4.15 (s, $4 \mathrm{H}: \mathrm{CH}$ ), $7.1 \mathrm{br}$. s, $6 \mathrm{H} ; \mathrm{NH}) ;{ }^{1} \mathrm{H} \mathrm{NMR}\left(\mathrm{D}_{2} \mathrm{O}\right): \delta=2.56$ (br.s. $\left.2 \mathrm{H} ; \mathrm{SiCH}_{2} \mathrm{~N}\right), 4.68(\mathrm{~s}, 4 \mathrm{H} ; \mathrm{CH}) ;{ }^{13} \mathrm{C}$ NMR ([D $]$ DMSO): $\delta=28.2\left(\mathrm{SiCH}_{2} \mathrm{~N}\right), 75.5(\mathrm{CH}) .173 .3(\mathrm{C}=\mathrm{O}) ;{ }^{13} \mathrm{C}$ NMR $\left(\mathrm{D}_{2} \mathrm{O}\right): \delta=29.3\left(\mathrm{SiCH}_{2} \mathrm{~N}\right), 77.7(\mathrm{CH}), 178.2(\mathrm{C}=\mathrm{O}) ;{ }^{29} \mathrm{Si} N \mathrm{NM}\left(\left[\mathrm{D}_{6}\right] \mathrm{DMSO}\right)$ : $\delta=-91.7 ;{ }^{29} \mathrm{Si}$ NMR $\left(\mathrm{D}_{2} \mathrm{O}\right): \delta=-90.0 ; \mathrm{FAB}-\mathrm{MS}$ (glycerol as matrix, xenon as neutral gas), $m / z(\%): 409(100)\left[M-H^{+}\right], 411(100)\left[M+H^{+}\right]$.

$(+)-4 \cdot 3 \mathrm{H}_{2} \mathrm{O}:$ M.p. $>350 \mathrm{C}:[\alpha]_{589}^{20}=+84$ (DMSO, $c=1.14$ ); correct C, H. N analysis. The ${ }^{1} \mathrm{H},{ }^{13} \mathrm{C}$. and ${ }^{29} \mathrm{Si} \mathrm{NMR}$ data and the FAB-MS data were identical with those obtained under the same measurement conditions as used for $(+)-4$ [exception: an additional resonance signal in the ${ }^{1} \mathrm{H}$ NMR spectrum ([D, ]DMSO) at $\delta=3.35\left(\mathrm{~s}, 6 \mathrm{H} ; \mathrm{H}_{2} \mathrm{O}\right)$ ).

Received: January 12, 1994 [Z6609!E]

German version: Angew. Chen. 1994. 1(16. 1250

[1] Reviews: a) W. S. Sheldrick in The Chemistry of Organic Silicon Compounds. Part 1 (Eds.: S. Patai, Z. Rappoport), Wiley. Chichester, 1989, pp. 227-303; b) R. R. Holmes, Chem. Rev. 1990, 90.17-31; c) C. Chuit. R. J. P. Corriu. C. Reye. J. C. Young, ibid. 1993, 93, $1371 \cdot \cdot 1448$.

[2] Original publications: a) C. Strohmann. R. Tacke, G. Mattern. W. F. Kuhs, J. Organomer. Chem. 1991, 403.63-71; b) R. Tacke, J. Sperlich. C. Strohmann. G. Mattern, Chem. Ber. 1991, 124, 1491-1496; c) R. Tacke. J. Sperlich. C. Strohmann, B. Frank, G. Mattern, Z. Kristallogr. 1992, 199, 91-98: d) R. Tacke, F. Wiesenberger, A. Lopez-Mras. J. Sperlich, G. Mattern, Z. Naturforsch. B 1992, 47, 1370-1376; e) R. Tacke, A. Lopez-Mras. J. Sperlich, C. Strohmann, W. F. Kuhs, G. Mattern. A. Sebald, Chem. Ber. 1993. 126,851861; f) R. Tacke, A. Lopez-Mras, W. S. Sheldrick. A. Sebald. Z. Anorg. Altg. Chem, 1993, 619, 347-358; g) J. Sperlich, J. Becht, M. Mühleisen. S. A. Wagtner, G. Mattern, R. Tacke, Z. Naturforsch. B 1993. 48. 1693-1706: h) R. Tacke, A. Lopez-Mras, P. G. Jones. Organometallic's, in press.

[3] Review: R. Tacke, J. Becht. A. Lopez-Mras. J. Sperlich, J. Organomet. Chem. 1993, 446, $1-8$

[4] Synthesis: J. E. Noll, J. L. Speier, B. F. Daubert. J. Am. Chem. Soc. 1951. 73. 3867-3871.

[5] The levorotatory antipode (-)-4 [(-)-4.3 $\left.\mathrm{H}_{2} \mathrm{O}\right]$ can be obtained hy the reaction of 3 with $(S, S)-(-)$-tartaric acid in an analogous manner.

[6] Crystal data for ( + ) $-4 \cdot 3 \mathrm{H}_{2} \mathrm{O}: \mathrm{C}_{10} \mathrm{H}_{20} \mathrm{~N}_{2} \mathrm{O}_{15} \mathrm{Si}_{2}$, monoclinic, space group $P 2_{1}$, $a=815.2(3), \quad b=1045.1(4), \quad c=1089.1(3) \mathrm{pm}, \quad \beta=103.06(3) " . \quad V=$ $0.9039(5) \mathrm{nm}^{3}, Z=2$. $T=-130^{\circ} \mathrm{C}$. A colorless prism $(0.90 \times 0.15 \times$ $0.15 \mathrm{~mm}$ ) was mounted in inert oil (type RS3000; donation from Riedel dc Haën). 5624 Intensities were measured on a diffractometer (Stoe, type STADI-4) $\left(\mathrm{Mo}_{\mathrm{Kx}}\right.$ radiation, $\left.2 \theta_{\max }=60^{\circ}\right)$. of which 5299 were independent $\left(R_{\text {int }}=0.035\right)$. The structure was solved by direct methods and refined on $F^{2}$ (program SHELXL-93, G. M. Sheldrick, Universität Göttingen). The final $R_{w}\left(F^{2}\right)$ value was 0.111 , the conventional $R(F)$ value was 0.043 (for 282 parameters). The absolute configuration of $(+)-4$ was confirmed by means of an $x$ refinement $[x=0.02(11)]$ (cf. H. D. Flack, Acta Crystallogr. Sect, A 1983. 39. 876-881). Further details of the crystal structure investigation may be obtained from the Fachinformationszentrum Karlsruhe, D-76344 EggensteinLeopoldshafen (FRG) on quoting the depository number CSD-400670.

[7] The quantification of the distortion in this form relates to the transition from the ideal trigonal bipyramid toward the ideal square pyramid along the reaction coordinate of the Berry pseudorotation. The degree of distortion was calculated according to the dihedral angle method described in the literature [10]. using the values given there for the reference geometry of the ideal square pyramid. 
[8] Measurement conditions: $250.1\left({ }^{1} \mathrm{H}\right) .62 .9\left({ }^{13} \mathrm{C}\right)$, and $49.7 \mathrm{MHz}\left({ }^{29} \mathrm{Si}\right)$; approx. $22 \mathrm{C}$ : $\left[\mathrm{D}_{5}\right] \mathrm{DMSO}(\delta=2.49)$ and $\left(\mathrm{CH}_{3}\right)_{3} \mathrm{Si}\left(\mathrm{CH}_{2}\right)_{3} \mathrm{SO}_{3} \mathrm{Na}(\delta=0)$ as internal ' $\mathrm{H}$ standards in $\left[\mathrm{D}_{6}\right] \mathrm{DMSO}$ or $\mathrm{D}_{2} \mathrm{O} ;\left[\mathrm{D}_{6}\right] \mathrm{DMSO}(\delta=39.90)$ and $\left(\mathrm{CH}_{3}\right)_{3} \mathrm{Si}\left(\mathrm{CH}_{2}\right)_{3} \mathrm{SO}_{3} \mathrm{Na}(\delta=0)$ as internal ${ }^{13} \mathrm{C}$ standards in $\left[\mathrm{D}_{6}\right] \mathrm{DMSO}$ or $\mathrm{D}_{2} \mathrm{O}$ : TMS $(\delta=0)$ and $\left(\mathrm{CH}_{3}\right)_{3} \mathrm{Si}\left(\mathrm{CH}_{2}\right)_{3} \mathrm{SO}_{3} \mathrm{Na}(\delta=0)$ as internal ${ }^{29} \mathrm{Si}$ standards in $\left[\mathrm{D}_{6}\right] \mathrm{DMSO}$ or $\mathrm{D}_{2} \mathrm{O}$.

[9] C. W. Sullivan in Silicon Biochemistry (Eds. : D. Evered, M. O'Connor). Wiley, Chichester, 1986, pp. 59-89, and references therein

[10] R. R. Holmes. J. A. Deiters, J. Am. Chem. Soc. 1977, 99. 3318-3326.

\section{$\left[\mathrm{Zr}_{3} \mathrm{Cp}_{2}\left(\mathrm{O}_{2} \mathrm{CNiPr}_{2}\right)_{6}\left(\mu_{3}-\mathrm{O}\right)\left(\mu_{2}-\mathrm{CCO}\right)\right]$, the First Crystallographically Established Ketenylidene Complex; A Model for CO Reductive Cleavage on Metal Surfaces**}

Fausto Calderazzo, Ulli Englert, Alessandro Guarini, Fabio Marchetti, Guido Pampaloni,* and Annalaura Segre

The formation of carbon-carbon bonds from the $C_{t}$ feedstock, $\mathrm{CO}$, is a fundamental reaction in organometallic chemistry. Reductive coupling of $\mathrm{CO}$ to give fragments containing C-C multiple bonds has been reported. ${ }^{[1]}$ In these reactions exhaustive transfer of oxygen from $\mathrm{CO}$ to cations of early transition metals, lanthanides, or actinides occurs. On the other hand, less extensive reductions of carbon monoxide occurs with alkali metals or solutions of them to yield (CO) ${ }_{n}^{m-}$ species, $n=m=2 ;{ }^{[2]} n=4$, $m=2 ; i^{[3]} n=m=6 .^{[4]}$ To our knowledge, only one case exists ${ }^{[5 a}$ of the intermediate reduction of $\mathrm{CO}$ to the ketenylidene ligand, namely in the reaction of $\left[\mathrm{Ta}\left(t \mathrm{Bu} \mathrm{SiO}_{3} \mathrm{SiO}\right)_{3}\right.$ with $\mathrm{CO}$ at low temperature and pressure, which gives an almost equimolar mixture of $\left[\mathrm{TaO}\left(t \mathrm{Bu}_{3} \mathrm{SiO}\right)_{3}\right]$ and $\left[\mathrm{Ta}(\mathrm{CCO})\left(t \mathrm{Bu}_{3} \mathrm{SiO}_{3}\right]\right.$; the latter compound is not isolated, but contains a terminal ketenylidene ligand according to spectroscopic data. The reaction of $\left[\mathrm{Sm}\left(\mathrm{C}_{5} \mathrm{Me}_{5}\right)_{2}(\text { thf })_{2}\right]$ with $\mathrm{CO}$ was reported to yield the metalsubstituted ketenecarboxylic acid in $\left[\mathrm{Sm}_{2}\left(\mathrm{C}_{5} \mathrm{Me}_{5}\right)_{4}\left(\mathrm{O}_{2} \mathrm{CCCO}\right)\right.$ (thf) $]_{2} \cdot{ }^{[5 b]}$

In continuation of our studies on redox reactions with $N, N$ dialkylcarbamato complexes of transition elements, ${ }^{[6]}$ we now report ${ }^{[7]}$ that the reaction of $\left[\mathrm{Cp}_{2} \mathrm{Zr}(\mathrm{CO})_{2}\right]$ with $\left[\mathrm{Zr}\left(\mathrm{O}_{2} \mathrm{CNR}_{2}\right)_{4}\right]$ $(\mathrm{R}=\mathrm{Et}, i \mathrm{Pr})$ in refluxing toluene affords colorless crystals of the diamagnetic compounds $1 \mathbf{a}(\mathrm{R}=\mathrm{Et})$ and $\mathbf{1} \mathbf{b}(\mathrm{R}=i \mathrm{Pr})$ in satisfactory yields [Eq. (a)].

$\left[\mathrm{Cp} 2 \mathrm{Zr}(\mathrm{CO})_{2}\right] \stackrel{\left[\mathrm{Zr}\left(\mathrm{O}_{2} \mathrm{CNR}_{2}\right)_{4}\right]}{\longrightarrow}\left[\mathrm{Zr}_{3} \mathrm{Cp}_{2}\left(\mathrm{O}_{2} \mathrm{CNR}_{2}\right)_{6}\left(\mu_{3}-\mathrm{O}\right)\left(\mu_{2}-\mathrm{CCO}\right)\right]$

Compounds 1 are poorly soluble in aliphatic hydrocarbons and slightly soluble in aromatic hydrocarbons and THF. The

[*] Prof. G. Pampaloni, Prof. F. Calderazzo, Dr. F. Marchetti

Dipartimento di Chimica e Chimica Industriale,

Sezione di Chimica Inorganica

Via Risorgimento 35, 1-56126 Pisa (1taly)

Telefax: Int. code $+(50) 20237$

Dr. U. Englert

Institut für Anorganische Chemie der Technischen Hochschule Aachen (FRG)

Dr. A. Guarini

ENIChem. Istituto Guido Donegani, Novara (Italy)

Dr. A. Scgre

istituto C. N. R. di Strulturistica Chimica "G. Giacomello", Roma (Italy)

[**] This work was supported by the Consiglio Nazionale delle Ricerche (CNR, Roma), Progetto Finalizzato Chimica Fine II. The authors wish to thank Prof. A. Zecchina, Università di Torino, for helpful discussions. $\boldsymbol{\mu}$-ketenylidene derivatives $\mathbf{I}$ are characterized by a sharp IR absorption at $2013 \mathrm{~cm}^{-1}$ (in toluene or as nujol mull), which shifts to $1951 \mathrm{~cm}^{-1}$ in the ${ }^{13} \mathrm{C}$-labeled compound prepared from $\left[\mathrm{Cp}_{2} \mathrm{Zr}\left({ }^{13} \mathrm{CO}\right)_{2}\right]$ and $\left[\mathrm{Zr}\left(\mathrm{O}_{2} \mathrm{CNiPr}\right)_{4}\right]$, thus showing that the carbon atoms of the $\mu$-ketenylidene ligand come from the carbonyl groups of the zirconium(II) complex. No shift of the $2013 \mathrm{~cm}^{-1}$ band is observed in the compound obtained from the reaction of $\left[\mathrm{C}_{2} \mathrm{Zr}(\mathrm{CO})_{2}\right]$ with $\left[\mathrm{Zr}\left(\mathrm{O}_{2}{ }^{13} \mathrm{CNiPr}_{2}\right)_{4}\right]$.

The ${ }^{13} \mathrm{CNMR}$ spectrum of the ${ }^{13} \mathrm{C}$-labeled product $\left[\mathrm{Zr}_{3} \mathrm{Cp}_{2}\left(\mathrm{O}_{2} \mathrm{CN} i \mathrm{Pr}_{2}\right)_{6}\left(\mu_{3}-\mathrm{O}\right)\left(\mu_{2^{-}}{ }^{13} \mathrm{C}^{13} \mathrm{CO}\right)\right]$ shows two doublets at $\delta=181.5$ and $112.4\left(J_{C, C}=78.9 \mathrm{~Hz}\right)$; the former resonance is assigned to the carbon adjacent to the oxygen atom of the ketenylidene ligand, in agreement with the reported values for bridging ketenylidene groups. $^{[8]}$

Figure 1 shows the molecular structure ${ }^{[9]}$ of $1 \mathbf{b}$, which consists of a $\mu_{3}$-O-bridged triangle of zirconium atoms. Two of the metal atoms $(\mathrm{Zr} 2$ and $\mathrm{Zr} 3)$ are coordinated to bridging carbamates and to the cyclopentadienyl and $\mu$-CCO ligands; the third zirconium atom $(\mathrm{Zr} 1)$ has bridging and terminal carbamato ligands. A similar essentially planar $\mathrm{Zr}_{3}\left(\mu_{3}-\mathrm{O}\right)$ moiety has been observed ${ }^{[10]}$ in $\left[\mathrm{Zr}_{3} \mathrm{Cp}_{3}\left(\mu_{2}-\mathrm{OH}\right)\left(\mu_{3}-\mathrm{O}\right)\left(\mu_{2}-\mathrm{PhCOO}\right)_{3}\right]^{+} \mathrm{PhCOO}^{-}[\mathrm{Zr}-\mathrm{O}$ (mean value) $2.071(11) \AA, \mathrm{Zr}-\mathrm{O}-\mathrm{Zr}$ (mean value) $108.1(8)^{\circ} ; \mathrm{Zr} \cdots \mathrm{Zr}$ (mean value) $3.354(12) \AA$; see caption to Fig. 1 for the corresponding values for 1 b]. The $\mu$-ketenylidene ligand is substantially linear [C1-C2-O2, 179(1) ${ }^{\circ}$; the $\mathrm{C} 1-\mathrm{C} 2$ and the $\mathrm{C} 2-\mathrm{O} 2$ bond lengths of 1.31(2) and 1.24 (1) $\AA$, respectively, are in accord with the reported values. ${ }^{[8]}$

The ketenylidene ligand has been assembled around a transition metal cation by four synthetic methods: a) reductive dehalogenation or dehalogenation of a metal-coordinated $\mathrm{C}$ $X_{n}$ fragment, such as the dehalogenation ${ }^{[1]}$ of $\left[\mathrm{Co}_{3}(\mathrm{CO})_{9} \mathrm{C}-\mathrm{Cl}\right]$ by $\mathrm{AlCl}_{3}$ in the presence of $\mathrm{CO} ; \mathrm{b})$ reductive cleavage (by an external reducing agent such as an

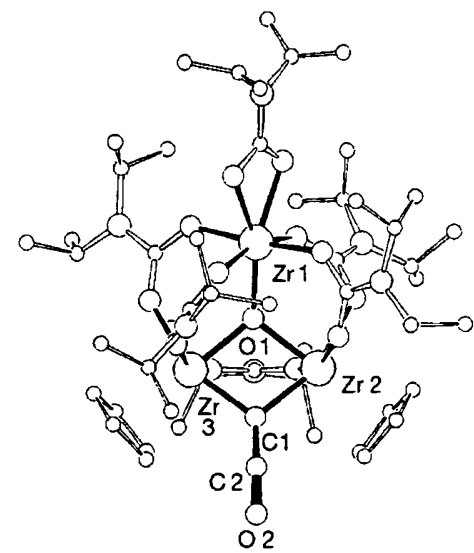

Fig. 1. Crystal structure of $1 \mathrm{~b}$ [19]. Selected distances $[\AA]$ and angles $\left[{ }^{\circ}\right]: \mathrm{Zr} 1-012.049(5)$, $\mathrm{Zr} 2-012.140(5), \mathrm{Zr} 3-012.126(5), \mathrm{Zr} 2-\mathrm{Cl}$ $2.122(8), \mathrm{Zr} 3-\mathrm{C} 12.138(8), \mathrm{Zr} \cdots \mathrm{Zr}$ (mean value) $3.597(1) ; \mathrm{Zr} 1-\mathrm{O} 1-\mathrm{Zr} 2125.0(2), \mathrm{Zr} 1-\mathrm{O} 1$ $\mathrm{Zr} 3$ 130.0(3), $\mathrm{Zr2}-\mathrm{O} 1-\mathrm{Zr} 3$ 103.8(2), O1-Zr2C1 73.7(2), O1-Zr3-Cl 73.6(2), $\mathrm{Zr2}-\mathrm{C} 1-\mathrm{Zr} 3$ 104.0(4), $\mathrm{Zr} 2 \cdot \mathrm{C} 1-\mathrm{C} 2$ 126.8(8), $\mathrm{Zr} 3-\mathrm{C} 1-\mathrm{C} 2$ $128.1(8)$. clear or tetranuclear metal cluster of a $\mathrm{CO}$ single bond obtained by a preliminary electrophilic activation of a metal-coordinated carbonyl group $;{ }^{[12]} \mathrm{c}$ ) reaction of a low-valent metal complex with $\mathrm{C}_{3} \mathrm{O}_{2} ;{ }^{[13]}$ d) carbonylation of a diazomethyl complex. ${ }^{[1]}$ Furthermore, a silver ketenylidene complex has been prepared $^{[15]}$ from a silver salt and ketene or ketene precursors. The isolation of compounds 1 corresponds to a new preparative method by which the $\mathrm{Zr}$-coordinated carbonyl groups are reduced to the $\mu_{2}$-ketenylidene ligand without addition of an external reducing agent. The four reducing equivalents required by this process $\left(2 \mathrm{CO} \rightarrow \mathrm{C}_{2} \mathrm{O}+\mathrm{O}\right)$ are provided by zirconium(II).

The proximity of the metal atoms in 1 may establish similar conditions to those at a metal surface on which an analogous process might take place. The simplicity and the high chemoselectivity of the reaction reported in this paper, and the high 